\title{
Upaya Meningkatkan Hasil Belajar IPA Siswa Kelas IV SDN 01 Mukomuko Menggunakan Media Torso
}

\author{
Julaila ${ }^{1}$ \\ 1,State Elementery School 01 City of Mukomuko. Bengkulu \\ Coressponding Author. E-mail: \\ 1 julaila04@gmail.com \\ Received: 11 November 2018 \\ Accepted: 14 Desember 2018 \\ Online Published: 13 Januari 2019
}

\begin{abstract}
Abstrak
Kemampuan siswa dalam menguasai materi pelajaran IPA sering kali menjadi perhatian bagi pengajar IPA di sekolah. Hal ini dikarenakan, kemampuan tersebut akan berpengaruh banyak pada hasil belajar siswa. Siswa kelas 4 SD Negeri 01 Mukomuko pun mengalami hal demikian. Hasil belajar siswa yang didapatkan dari pretest pada awal semester ganjil tahun ajaran 2017/2018 memiliki rata-rata hasil belajar yang relatif rendah. Setelah dilakukan penelusuran awal didapatkan bahwa guru jarang menggunakan media untuk pembelajaran. Sehingga siswa sulit menguasai materi pelajaran. Oleh karena itu perlu dilakukan perbaikan pembelajaran agar rata-rata hasil belajar IPA siswa meningkat. Untuk meningkatkan hasil belajar siswa, metode penelitian yang digunakan yang tepat adalah dengan menggunakan metode penelitian tindakan kelas. Penelitian ini terdiri dari 2 siklus. Media pembelajaran yang digunakan adalah Torso yang menjadi model dari tubuh manusia. Pada siklus I terdapat 2 siswa dari 21 siswa yang tidak memenuhi KKM. Sedangkan pada siklus II KKM terpenuhi hingga 100\%. Sehingga dengan demikian media torso yang digunakan dalam pembelajaran ini dapat membantu meningkatkan hasil belajar siswa pada siklus II
\end{abstract}

Kata Kunci: Penelitian Tindakan Kelas, Media Torso, Hasil Belajar.

\section{Efforts to Improve $4^{\text {th }}$ Grade Students Science Learning Outcomes of State Elementery School 01 Mukomuko Using Media Torso}

\begin{abstract}
Students' ability to mastery science is often a concern for science teachers at school. Because this ability will have a lot of influence on student learning outcomes. 4th grade students of SD Negeri 01 Mukomuko also experienced this. Student learning outcomes obtained from the pretest at the beginning of the odd semester of the 2017/2018 academic year have averagely has low learning outcomes. After an initial search, it was found that teachers rarely use media for learning. So students difficult to mastery the subject matter. Therefore it is necessary to improve learning so that the average student science learning outcomes increase. To improve student learning outcomes, the appropriate research method used is to use class action research methods. This study consisted of 2 cycles. The learning media used is a torso which is a model of the buman body. In the first cycle there were 2 students from 21 students who did not meet the KKM. While in the second cycle KKM is fulfilled up to 100\%. So that the torso media used in this learning can help improve student learning outcomes in the second cycle
\end{abstract}

Keywords: Classroom Action Research, Torso Media, Learning Outcome 


\section{PENDAHULUAN}

IPA merupakan salah satu mata pelajaran yang menunjang ilmu pengetahuan dan teknologi, dimana proses pembelajaran IPA menuntut pengalaman langsung siswa agar dapat mengembangkan kemampuannya untuk menjalahi dan memahami alam sekitar. Hal ini dinyatakan BSNP (2006:484) bahwa "IPA merupakan proses pembelajaran yang menekankan pada pengalaman langsung untuk mengembangkan kompetensi dalam menjelajahi dan memahami alam sekitar secara ilmiah". Dalam pembelajaran Ilmu Pengetahuan Alam (IPA), siswa dituntut aktif dalam belajar, sebab pelajaran IPA merupakan serangkaian kegiatan proses ilmiah diantarnya penyelidikan, penyusunan, dan pengkajian gagasan serta penanaman konsep.

Salah satu usaha yang dapat dilakukan guru dalam rangka meningkatkan mutu pendidikan adalah mengupayakan bagaimana siswa dapat belajar sehingga informasi yang diperolehnya dapat diproses dengan baik dan bertahan lama dalam pikirannya. Maka perlu diupayakan iklim belajar yang menyenangkan melalui penggunaan pendekatan yang tepat untuk mengembangkan potensi siswa secara utuh dan optimal.

Pelaksanaan pembelajaran IPA di SD diharapkan dapat mencapai tujuan, sesuai dengan yang dikemukakan Depdiknas (2006:464) yaitu :

1. Agar siswa memiliki kemampuan untuk memahami konsep-konsep IPA dan keterkaitannya dengan kehidupan seharihari,

2. Memiliki keterampilan proses untuk mengembangkan pengetahuan dan gagasan tentang alam sekitar,

3. Mempunyai minat untuk mengenal dan mempelajari benda-benda serta kejadian di lingkungan sendiri,

4. Bersikap ingin tahu, tekun, kritis, mawas diri, bertanggu jawab, bekerja sama, dan mendiri,

5. Mampu menerapkan konsep IPA untuk menyelesaikan gejala-gejala alam dan memecahkan masalah dalam kehidupan,

6. Mampu menggunakan teknologi sederhana yang berguna untuk memecahkan suatu masalah yang ditemukan dalam kehidupan sehari-hari.

Tujuan yang diharapkan dari depdiknas tadi belum dapat tercapai dari kelas yang peneliti ampu. $\mathrm{Hal}$ ini dapat dilihat dari hasil belajar yang masih rendah dari pencapaian raport yang telah diterima oleh siswa semester lalu. Rendahnya tingkat kemampuan murid menguasai materi pelajaran IPA karena dalam proses belajar mengajar, yang diterapkan guru selama ini berdasarkan hasil analisis adalah kemungkinan dalam pemberian materi tanpa alat peraga, membacakan naskah pelajaran sementara murid di minta mendengarkan dan mencatat, sehingga menjadi murid hanya sekedar sebagai pendengar pasif dalam kelas yang menyebabkan murid kurang berminat, bahkan bisa kehilangan motivasi belajarnya. Dengan demikian, tingkat pemahaman murid terhadap materi pelajaran atau hasil belajar yang diperoleh murid bisa berakibat rendah. Hal tersebut mengakibatkan hasil yang diperoleh nilai pelajaran IPA pada US (Ujian Semester) semester I tahun 2017 hanya memperoleh rata-rata 65 .

Untuk meningkatkan hasil belajar murid, maka salah satu cara yang diharapkan dapat meningkatkan kemampuan dan prestasi murid adalah dengan menggunakan media model torso yang membuat murid lebih mudah mengerti dan memahami materi yang disampaikan oleh guru. Penggunaan media torso sangat penting karena terkait dengan keberhasilan dan kemampuan murid secara utuh. Torso merupakan jenis media tiga dimensi yang dapat membantu murid dalam belajar, sebab secara langsung murid berhadapan dengan objek yang sedang dipelajari. Selama ini di SD Negeri 01 Kota Mukomuko tidak pernah belajar dengan menggunakan media torso, utamanya pada konsep rangka, sehingga murid kurang paham akan materi tersebut. Berkaitan dengan hal tersebut maka perlu dilakukan penelitian tentang penggunaan media model torso dalam pembelajaran IPA untuk meningkatkan hasil belajar murid, khususnya kelas IV.

Berdasarkan uraian sebelumnya, maka peneliti merasa perlu melakukan pengkajian secara ilmiah. Untuk maksud tersebut maka perlu dilakukan penelitian dengan judul "Penggunakan Media Torso dapat Meningkatan Hasil Belajar IPA Siswa Kelas IV SD Negeri 01 Kota Mukomuko". 


\section{KAJIAN PUSTAKA}

Pembelajaran IPA di SD dapat menjadi wahana bagi siswa untuk mempelajari diri sendiri dan alam sekitar prospek perkembangan lebih lanjut dalam menerapkannya dalam kehidupan sehari-hari proses pembelajaran menekankan pada pemberian pengalaman langsung untuk mengembangkan kompetensi agar menjelajahi dan memahami alam sekitar secara ilmiah. Wahana bagi siswa untuk mempelajari diri sendiri dan alam sekitar. Secara ilmiah Depdiknas (2006 : 484) menyatakan " Pendidikan IPA diharapkan dapat menadi wahana bagi siswa untuk mempelajari diri sendiri dan alam sekitar".

Pendapat Connant (dalam Usman, 2006:1) bahwa IPA adalah suatu deretan konsep serta skema konseptual yang berhubungan antara satu materi dengan materi lainnya yang tumbuh sebagai hasil eksperimentasi dan observasi, yang berguna untuk dieksperimenkan lebih lanjut.

Lebih lanjut Iskandar (1996:15) mendefinisikan IPA SD sebagai berikut: 1) mengamati apa yang terjadi, 2) mencoba memahami apa yang diamati tersebut, 3) mempergunakan pengetahuan baru untuk meramalkan apa yang akan terjadi, 4) menguji ramalan-ramalan untuk membuktikan apakah ramalan-ramalan tersebut benar atau tidak.

Kemudian Syahrudin (2008:19) mengatakan bahwa IPA adalah sebuah pengetahuan teoritis yang tersusun dengan adanya proses observasi, eksperimentasi, penyimpulan dan mengaitkan antara cara yang satu dengan cara yang lainnya.

Ruang Lingkup IPA adalah makhluk hidup dan proses kehidupannya benda-benda dan sifatsifatnya energi dan perubahannya serta bumi dan alam semesta. Hal ini diungkapkan BSNP (2006: 485) ruang lingkup IPA seperti makhluk hidup dan proses kehidupan yang diantaranya manusia, hewan, dan tumbuhan dan interaksinya dengan lingkungan serta kesehatan. Benda/materi sifatsifat dan kegunaannya yang meliputi: padat, cair, dan gas. Energi dan perubahan yang meliput: gaya, bumi, panas, magnet, listerik, dan cahaya. Bumi dan Alat semesta meliputi: tanah, bumi, tata surya, dan benda langit lainnya. Sains, lingkungan, teknologi dan masyarakat (Slingtemas) merupakan penerapan konsep sains dan saling keterkaitannya dengan lingkungan, teknologi dan masyarakat melalui suatu karya teknologi sederhana.

Dari pendapat diatas dapat disimpulkan bahwa ruang lingkup pembelajaran IPA SD adalah
: proses kehidupannya, benda/materi, sifat-sifat dan kegunaannnya, energi dan perubahannya, bumi dan alam semesta dan Sains, lingkungan, teknologi dan masyarakat.

Dalam perkembangannya, IPA diterjemahkan sebagai IPA, meskipun pengertian ini kurang pas dan bertentangan dengan etimologi namun istilah tersebut masih sering digunakan. IPA berkaitan dengan cara mencari tahu tentang alam secara sistematis sehingga IPA bukan hanya penguasaan kumpulan pengetahuan yang berupa faktor-faktor, konsep-konsep atau prinsip-prinsip saja, tetapi oleh adanya metode ilmiah seperti observasi dan eksperimen dan sikap ilmiah seperti rasa ingin tahu, terbuka, jujur, dan sebagainya.

IPA sebagai produk isi mencakup fakta, konsep, prinsip, hukum-hukum, dan teori. Pada hakikatnya IPA terdiri dari tiga komponen, yaitu sikap ilmiah, proses ilmiah, dan produk ilmiah. $\mathrm{Hal}$ ini berarti bahwa IPA tidak hanya terdiri atas kumpulan pengetahuan atau berbagai macam fakta yang dihafal, IPA juga merupakan kegiatan atau proses aktif menggunakan pikiran dalam mempelajari gejala-gejala alam yang belum dapat direnungkan.

Muchtar, dkk (2004: 5) menjelaskan bahwa prinsip-prinsip pembelajaran dalam mata pelajaran Ilmu Pengetahuan Alam di sekolah dasar sebagai berikut:

a. Materi pembelajaran disusun berdasarkan penyesuaian terhadap Kurikulum Berbasis Kompetensi sesuai standar isi 2006

b. Pemberian ilustrasi. Dimaksudkan untuk memberikan penjelasan kepada murid dengan mempergunakan contoh-contoh gambar dari setiap materi belajar dan untuk menarik minat murid terhadap mata pelajaran Ilmu Pengetahuan Alam.

c. Aktivitas kegiatan. Merupakan penerapan percobaan-percobaan yang dilakukan murid baik individu maupun kelompok yang bertujuan agar murid memiliki pengalaman nyata dalam memahami suatu materi pelajaran yang diberikan.

d. Akttivitas tugas. Pemberian tugas baik individu maupun kelompok dimaksudkan agar murid aktif dan dapat memecahkan masalah yang ditemukan.

Media pengajaran yang dipilih dalam penelitian ini menggunak media pembelajaran Torso. Pilihan media dalam pengajaran tidak 
didasarkan kepada kualitas dan harga media akan tetapi lebih kepada fungsi dan peranannya dalam membantu kegiatan pembelajaran yang dilaksanakan.

Penggunaan media atau alat peraga dipilih berdasarkan fungsi dan peranannya dalam pembelajaran. Torso adalah sebuah istilah anatomi untuk bagian tengah dari tubuh manusia yang merupakan media pembelajaran jenis model penampang (cutaway model) yang digunakan untuk pembelajaran Ilmu Pengetahuan Alam. Anonim (2010) Torso merupakan "bentuk atau model yang mempunyai ukuran yang dapat lebih besar dari ukuran aslinya atau bahkan dapat lebih kecil dari ukuran sebenarnya".Torso sebagai salah satu jenis media pembelajaran yang termasuk dalam klasifikasi media tiga dimensi.

Media torso dapat memperlihatkan bagaimana sebuah objek itu tampak, apabila bagian permukaannya diangkat untuk mengetahui susunan bagian dalamnya. Model penampang atau dikenal dengan istilah X-Ray atau alat peraga torso digunakan untuk memperlihatkan susunan anatomi organ tubuh yang vital seperti mata, jantung, hati, usus dan sebagainya.

Penggunaan torso dalam kegiatan pembelajaran dapat memberikan pemahaman yang lebih tepat kepada murid, karena murid dapat secara langsung mengamati dan mengetahui bentuk sesungguhnya. Torso akan mempermudah murid memahami objek tertentu, karena model tersebut dapat diubah dimensi dan ukurannya yang lebih besar dari ukuran semestinya. Akan tetapi dalam menggunakan torso pada pembelajaran Ilmu Pengetahuan Alam terdapat beberapa hal yang perlu diperhatikan oleh guru diantaranya adalah bahwa dalam membuat penampang seyogyanya menonjolkan hal-hal yang penting saja dengan penanda atau dengan memberikan warna yang terang sementara rincian yang tidak begitu penting dapat dihilangkan.

Penerapan media torso dalam pembelajaran dengan langkah-langkah sebagai berikut :

1. Guru mempersiapkan torso yang sesuai dengan materi yang akan dipelajari.

2. Guru mempersiapkan LKM (Lembar Kerja Murid) dan petunjuk penggunaan media torso

3. Guru meletakkan media torso di depan kelas agar semua murid dapat melihat.
4. Guru membagikan LKM (Lembar Kerja Murid) pada tiap-tiap kelompok untuk didiskusikan

5. Murid mengamati torso

6. Murid pada tiap-tiap kelompok mempresentasikan hasil kelompoknya dan murid lain mengomentari

7. Kesimpulan.

Pengertian belajar, sebenarnya sudah banyak ahli yang telah mengemukakan pendapatnya. Para ahli memberikan definisi belajar sesuai dengan pandangan, latar belakang dan aliran masingmasing. Untuk lebih jelasnya dapat di kemukakan beberapa pengertian belajar berikut ini : Sardiman (1992 : 22-23) mengartikan belajar sebagai "Usaha penguasaan materi ilmu pengetahuan yang merupakan sebagian kegiatan menuju terbentuknya kepribadian seutuhnya". Belajar adalah "proses perubahan tingkah laku pada diri individu berkat adanya interaksi antara individu dan individu dengan lingkungannya" (Usman, 1995 : 5).

Sedangkan Morgan dkk dalam Departemen Pendidikan dan Kebudayaan (1998/1999: 7) mengungkapkan bahwa belajar "sebagai setiap perubahan tingkah laku yang relatif tetap dan terjadi sebagai hasil latihan dan pengalaman". Belajar adalah "suatu proses usaha yang dilakukan seseorang untuk memperoleh suatu perubahan tingkah laku yang baru secara keseluruhan, sebagai hasil pengalamannya sendiri dan interaksi dengan lingkungannya" (Slamento, 2010: 2). Chaplin dalam Syah (2009) mengartikan belajar sebagai "perolehan perubahan tingkah laku yang relatif menetap sebagai akibat latihan dan pengalaman". Hintsman dalam Syah (2009) berpendapat bahwa belajar adalah "suatu perubahan yang terjadi dalam organisme, manusia atau hewan, disebabkan oleh pengalaman yang dapat mempengaruhi tingkah laku organism tersebut". Sedangkan Syah (2009: 68) sendiri mengartikan belajar sebagai "tahapan perubahan seluruh tingkah laku individu yang relatif menetap sebagai hasil pengalaman dan interaksi dengan lingkungan yang melibatkan proses kognitif'.

Selanjutnya Pasaribu dkk (1982: 59) memberikan defenisi belajar sebagai "suatu proses perubahan kegiatan, reaksi terhadap lingkungan, perubahan tersebut tidak dapat disebut belajar apabila disebabkan oleh pertumbuhan atau keadaan sementara seseorang seperti kelelahan atau disebabkan obat-obatan". Skinner dalam Dimyati dkk (2009) belajar adalah "suatu perilaku". Gagne 
(Dimyati, 2009) belajar adalah "kegiatan yang kompleks".

Dari beberapa definisi yang telah dikemukakan, dapat diketahui bahwa setiap proses belajar yang dilakukan oleh seorang pada dasarnya memiliki ciri seperti berikut ini : (1) Belajar adalah aktivitas (kegiatan) yang mana menghasilkan perubahan pada diri seseorang yang belajar. (2) Pada prinsipnya perubahan itu adalah didapatnya kemampuan baru dan berlaku pada waktu yang relative lama. (3) Perubahan itu terjadi karena usaha dan kegiatan yang telah dilakukan sebelumnya. Jadi dapat disimpulkan bahwa belajar adalah proses perubahan tingkah laku seseorang melalui pengalaman, yang ditandai dengan adanya perubahan yang bersifat kualitatif dalam hal pengetahuan, sikap dan keterampilan yang dimiliki.

Hasil belajar pada hakikatnya adalah perubahan tingkah laku sebagai akibat belajar yang mencakup aspek kognitif, afektif dan psikomotorik. Hal tersebut sebagaimana menurut Winkel (1996: 244) bahwa "berdasarkan taksonomi Bloom, aspek belajar yang harus di ukur keberhasilannya adalah aspek kognitif, afektif dan psikomotorik sehingga dapat menggambarkan tingkah laku menyeluruh sebagai hasil belajar murid".

Ketiga aspek tersebut tidak berdiri sendiri, melainkan merupakan satu kesatuan yang tidak dapat dipisahkan dan mencakup beberapa jenjang yaitu :

1 Aspek kognitif adalah kemampuan intelektual yang mencakup jenjang : pengetahuan, pemahaman, penerapan, analisis, sintesis dan evaluasi.

2 Aspek afektif adalah perasaan emosi atau nilai. Afektif memiliki jenjang, yakni : penerimaan, tanggapan, penelitian, pengorganisasian, dan pemeran.

3 Aspek psikomotorik adalah kemampuan yang mengutamakan gerak perilaku yang melibatkan pemahaman yang dimiliki. Aspek psikomotorik memiliki jenjang, yakni; persepsi, kesiapan, penyesuaian dan kreativitas.

\section{METODE}

Metode penelitian ini menggunakan metode Penelitian Tindakan Kelas. Pelaksanaannya dilakukan 2 siklus. Setiap siklus terdiri dari empat tahapan, yaitu perencanaan (planning), pelaksanaan tindakan (action), pengamatan dan refleksi.

\section{Prosedur Umum}

Peneliti memberikan kegiatan perbaikan berdasarkan perumusan masalah yang telah dianalisis pada siklus pertama dan akan diperbaiki pada siklus yang kedua. Adapun yang menjadi fokus perbaikan pembelajaran pada setiap siklus adalah:

\section{a. Pra Siklus}

1. Meningkatkan ketrampilan guru dalam menggunakan media

2. Mengaktifkan siswa dalam belajar

3. Masih rendahnya prestasi belajar siswa

\section{b. Siklus I}

1. Meningkatkan ketrampilan guru dalam menggunakan media torso

2. Meningkatkan keaktifan siswa dalam belajar

3. Meningkatkan prestasi belajar siswa

\section{c. Siklus II}

1. Menggunakan media torso sehingga dapat menarik perhatian siswa

2. Memotivasi siswa dengan memberikan pujian dan hadiah.

\section{Prosedur Khusus}

1. Pra Siklus

$$
\text { a. Tahap Perencanaan }
$$

Tahap ini diawali dengan kegiatan observasi awal untuk mengidentifikasi masalah sehingga diperoleh permasalahan berdasarkan permasalahan tersebut. Dari permasalahan diperoleh dan direncanakan upaya perbaikan. Adapun perencanaan - perencanaan yang akan disusun pada kegiatan ini meliputi :

> Mempersiapkan satuan pelajaran yang akan diajarkan kepada siswa

$>$ Mempersiapkan media pembelajaran berupa alat peraga

> Mempersiapkan soal-soal sebagai alat evaluasi

b. Tahap Pelaksanaan

1) Kegiatan Awal (10 Menit)

$>$ Guru membuka pelajaran 
$>$ Guru mulai menjelaskan dasar - dasar materi

> Guru melakukan apersepsi

2) Kegiatan Inti ( 45 Menit )

$>$ Guru menjelaskan materi tentang rangka secara umum

$>$ Guru dan siswa bertanya jawab secara lisan

$>$ Guru memberikan evaluasi

3) Kegiatan Akhir (15 Menit)

$>$ Pemantapan konsep

$>$ Pemberian tugas rumah tentang kegunaan rangka

c. Observasi

Observasi dilakukan terhadap peneliti sebagai guru dan siswa dengan pemberian soal. Observasi dilakukan untuk melihat hasil kegiatan guru dan siswa selama proses pembelajaran dilakukan.

\section{d. Refleksi Pra Siklus}

Berdasarkan hasil refleksi analisis dan observasi yang dilakukan oleh pengamat, masih ditemukan beberapa aspek yang pelaksanaannya belum berjalan dengan baik dan masih harus diperbaiki, serta ketidak tuntasan hasil belajar siswa yang masih perlu ditingkatkan. Guru memberikan tindak lanjut pada pelaksanaan Pra siklus dilaksanakan pengamatan terhadap kegiatan belajar mengajar yang sedang berlangsung dengan menggunakan lembar pengamatan kegiatan pembelajaran yang telah dibuat. Selama pelaksanaan kegiatan belajar mengajar observasi dilakukan oleh pengamat yaitu teman sejawat. Pengamat memberikan tanda $(\sqrt{ })$ terhadap aspek yang diamati. Pada akhir pelaksanaan Pra siklus diadakan evaluasi yang berupa tes tertulis yang berbentuk essay.

Setelah melaksanakan pembelajaran Pra siklus selanjutnya dilakukan refleksi dan analisis. Pada tahap ini dilakukan analisis terhadap seluruh hasil penilaian baik yang menyangkut penilaian proses maupun hasil. Hasil penilaian tersebut digunakan sebagai bahan untuk melakukan refleksi.

Hasil refleksi digunakan sebagai pedoman untuk menyusun rencana pembelajaran pada siklus I.

\section{Siklus I}

a. Tahapan perencanaan

1) Menelaah Kurikilum Tingkat Satuan Pembelajaran (KTSP) yang sesuai dengan materi pelajaran yang akan diajarkan yaitu sistem rangka manusia.

2) Menyusun dan mengembangkan Rencana Pelaksanaan Pembelajaran.

3) Menyediakan media pembelajaran yang sesuai dengan skenario pembelajaran yang telah ditetapkan

4) Membuat lembar observasi untuk melihat aktivitas guru dan murid kelas IV selama tindakan berlangsung

5) Membuat LKM Membuat soal-soal latihan untuk tes akhir belajar sebanyak 5 nomor

b. Tahap pelaksanaan tindakan

Pada tahap ini dilaksanakan kegiatan proses belajar mengajar dengan mengacu pada skenario pembelajaran yang telah dibuat dengan materi sistem rangka pada manusia. Rencana Pelaksanaan Pembelajaran yang telah dibuat sebelumnya oleh peneliti disesuaikan dengan silabus yang digunakan. Siklus 1 dilaksanakan selama $2 \quad \mathrm{X}$ pertemuan,masing-masing pertemuan dengan alokasi waktu 2 X 35 menit. Dengan indikator mendekripsikan struktur rangka manusia dan menjelaskan fungsi rangka manusia. Pembelajaran dilakukan secara berkelompok dengan menggunakan media torso.

\section{c. Tahap Pengamatan}

Pada tahap ini ada dua perlakuan yaitu observasi dan evaluasi. Pelaksanaan tahap observasi terhadap aktivitas murid sebanyak 21 orang secara langsung pada proses belajar mengajar. Dengan menggunakan lembar observasi yang meliputi : kehadiran murid, perhatian murid terhadap pembahasan materi pelajaran, pengamatan terhadap torso,keaktifan murid dalam bertanya, kerja sama dalam kelompok, mengganggu teman yang belajar mengambil giliran untuk berbagi tugas, kemampuan murid dalam mengemukakan pendapat, murid yang mengikuti pelajaran dari awal hingga akhir, dan perilaku murid dalam kelas. Pelaksanaan evaluasi yaitu memberikan tes berupa soal-soal latihan yang dilakukan pada akhir tindakan. 


\section{d. Analisis dan Refleksi}

Hasil yang diperoleh pada tahap observasi dikumpulkan, demikian pula hasil tes belajar murid, kemudian dianalisis dan direfleksi. Refleksi yang dimaksudkan untuk melihat apakah rencana telah terlaksana secara optimal atauperlu dilakukan perbaikan. Hasil analisis siklus I inilah yang dijadikan acuan penulis untuk merancang siklus II di mana yang dianggap bagus tetap dipertahankan sedangkan kekurangannya menjadi pertimbangan dan refisi pada siklus berikutnya.

\section{Siklus II}

\section{a. Tahap Perencanaan}

Sebelum pelaksanaan tindakan pada siklus II ini, terlebih dahulu dilakukan persiapan pelaksanaan pembelajaran berupa penyusunan rencana perbaikan pembelajaran seperti rencana pelaksanaan pembelajaran, lembar observasi, lembar kerja murid, media serta penilaian yang digunakan.

\section{b. Tahap Pelaksanaan Tindakan}

Hal-hal yang seharusnya dilakukan pada pelaksanaan tindakan adalah memahami rencana yang telah dirumuskan dan dimengerti bagaimana proses belajar dengan menggunakan media torso. Pada siklus ini guru merubah posisi kelompok menjadi lurus yang sebelumnya posisi kelompok berbentuk segitiga. Diharapkan proses pembelajaran lebih efektif dan efisien.

\section{c. Tahap Pengamatan}

Selama proses pembelajaran berlangsung dilakukan pengumpulan data dengan menggunakan lembar observasi.

\section{d. Analisis dan Refleksi}

Rangkaian kegiatan berupa perancanaan, pelaksanaan, pengamatan dan refleksi akhir. Setelah berdiskusi dengan guru kelas IV untuk melihat kegagalan dan keberhasilan yang terjadi dalam proses pembelajaran dan didapatkan hasil yang sangat memuaskan hal ini ditandai dengan meningkatnya nilai rata-rata hasil belajar dan juga meningkatnya jumlah ketuntasan belajar murid.

Setelah melaksanakan pembelajaran siklus II selanjutnya dilakukan refleksi dan analisis. Pada tahap ini dilakukan analisis terhadap seluruh hasil penilaian baik yang menyangkut penilaian proses maupun hasil. Pada tahap ini, dilakukan analisis terhadap hasil observasi dan evaluasi. Hasil dari analisis merupakan rekomendasi bagi penelitian ini.
1) Pelaksanaan Perbaikan

Pelaksanaan perbaikan ini telah dilaksanakan dalam 2 siklus, setiap siklusnya terdiri dari empat tahap, yaitu : ( 1 ). Perencanaan ( Planning ), ( 2 ). Pelaksanaan tindakan ( action), ( 3 ). Observasi (observation ), dan ( 4 ) Penilaian dan refleksi (reflection )) Arikunto, 2007 ).

2) Pengamatan data / Instrumen

Instrumen yang dibutuhkan dalam penelitian ini ada 2 yaitu :

\section{a. Lembar Observasi}

Lembar observasi digunakan untuk mengamati guru dalam mengajar dengan menerapkan metode diskusi.

b. Lembar Test.

Test dilakukan pada akhir pembelajaran (Post Test) yang bertujuan untuk mengetahui sampai dimana pencapaian siswa terhadap materi pelajaran yang telah diberikan. Tes yang digunakan adalah test tertulis yang berupa test essay. Soal test disusun berdasarkan tujuan pembelajaran dan kisi - kisi soal. Test tertulis ini digunakan untuk menilai ranah kognitif siswa.

\section{3) Refleksi}

Setelah melaksanakan pembelajaran selanjutnya dilakukan refleksi dan analisis. Pada tahap ini dilakukan analisis terhadap seluruh hasil penilaian baik yang menyangkut penilaian proses maupun hasil. Pada tahap ini, dilakukan analisis terhadap hasil observasi dan evaluasi. Hasil dari analisis merupakan acuan untuk melakukan perbaikan pada siklus selanjutnya atau cukup dan sesuai dengan prosedur yang ada. Data kualitatif dianalisis dengan deskriptif analitik, mengkategorikan dan mengklarisifikasikan data yang diperoleh berdasarkan analisis kaitan logisnya, kemudian ditafsirkan dan disajikan secara aktual dan sistematis.

Data hasil ceklist dianalisis dengan rata rata. Data dari angket dianalisis dengan persentase. Dari kedua analis tersebut di ramu agar menjadi satu kesimpulan yang bermakna.

Teknik Pengumpulan Data

\section{Observasi}

Dalam penelitian tindakan kelas, format observasi digunakan untuk merekam data proses belajar mengajar yang dilaksanakan. Adapun format observasi yang digunakan dalam penelitian ini terdiri dari dua, yaitu : a) format observasi 
aktivitas guru dan b) format observasi aktivitas murid.

\section{Dokumentasi}

Dokumentasi hasil belajar murid, yaitu hasil tes yang diberikan guru kepada murid sebagai alat ukur untuk mengetahui kemampuan atau hasil belajar murid setelah proses pembelajaran berlangsung.

\section{Teknik}

Tes adalah suatu kegiatan yang diberikan guru kepada murid untuk mengetahui hasil belajar atau kemampuan murid. Tes juga dapat diberikan sebagai alat ukur. Adapun tes yang digunakan yaitu tes tulis.

\section{Teknik Analis Data}

Data yang diperoleh dari hasil observasi selama proses belajar mengajar, selanjutnya dianalisis secara kualitatif-deskriptif sehingga dapat diketahui apakah penggunaan media torso sudah mencapai sasaran atau belum. Adapun hasil belajar dianalisis secara deskriptif sehingga dapat diketahui apakah hasil belajar dengan menggunakan media torso sudah mencapai sasaran atau bahkan tidak mencapai sasaran.

Rumus penentuan nilai hasil belajar yang digunakan :

$$
\text { Nilai }=\frac{\text { Jumlah Skor }}{\text { Jumlah Skor Maksimal }} x 100
$$

Indikator Keberhasilan

Indikator keberhasilan penelitian ini dapat dilihat dari meningkatnya proses belajar murid dengan menggunakan media torso dan meningkatnya nilai rata-rata belajar murid kelas IV secara klasikal yaitu mencarai $75 \%$ murid yang memperoleh skor minimum 65 dari skor ideal 100.

\section{HASIL DAN PEMBAHASAN}

\section{HASIL}

Pada setiap akhir pembelajaran siklus I, dan II, selalu diadakan tes evaluasi dan pengamatan. Hasil tersebut akan disajikan dalam bentuk yang memuat isi keseluruhan hasil/temuan yang diperoleh selama melaksanakan penelitian. Hasil tersebut diperoleh dari catatan-catatan peneliti sendiri dan catatan-catatan guru pendamping atau teman sejawat.

\section{Siklus 1}

Mengawali pertemuan ini guru melakukan apersepsi yaitu dengan mengadakan tes awal yang tujuannya untuk menjaga kesiapan anak dengan bertanya jawab seputar benda-benda di sekitar kita dan bentuknya, dan membaca tek bacaan kemudian membahas soal-soal yang ada di LKS. Kemudian guru bersama siswa menyimpulkan materi.

Dari hasil evaluasi/tes pada siklus I tersebut dengan KKM 65 diperoleh data pada tabel 1.

Tabel 1. Hasil Tes Siklus 1

\begin{tabular}{|c|c|c|c|c|}
\hline No & $\begin{array}{l}\text { Nama } \\
\text { Siswa }\end{array}$ & $\begin{array}{l}\text { Nilai } \\
\text { Siklus } \\
\text { II }\end{array}$ & $\begin{array}{l}\text { Tunt } \\
\text { as }\end{array}$ & $\begin{array}{l}\text { Belum } \\
\text { Tuntas }\end{array}$ \\
\hline 1. & $\mathbf{A}$ & 80 & $\sqrt{ }$ & \\
\hline 2. & B & 80 & $\sqrt{ }$ & \\
\hline 3. & $\mathrm{C}$ & 80 & $\sqrt{ }$ & \\
\hline 4. & D & 80 & $\sqrt{ }$ & \\
\hline 5. & $\mathbf{E}$ & 80 & $\sqrt{ }$ & \\
\hline 6. & $\mathbf{F}$ & 80 & $\sqrt{ }$ & \\
\hline 7. & G & 80 & $\sqrt{ }$ & \\
\hline 8. & $\mathbf{H}$ & 60 & & $\sqrt{ }$ \\
\hline 9. & I & 90 & $\sqrt{ }$ & \\
\hline 10. & $\mathbf{J}$ & 70 & $\sqrt{ }$ & \\
\hline 11. & $\mathbf{K}$ & 100 & $\sqrt{ }$ & \\
\hline 12. & $\mathbf{L}$ & 70 & $\sqrt{ }$ & \\
\hline 13. & $\mathbf{M}$ & 90 & $\sqrt{ }$ & \\
\hline 14. & $\mathbf{N}$ & 80 & $\sqrt{ }$ & \\
\hline 15. & $\mathbf{O}$ & 60 & & $\sqrt{ }$ \\
\hline 16. & $\mathbf{P}$ & 80 & $\sqrt{ }$ & \\
\hline 17. & $\mathbf{Q}$ & 70 & $\sqrt{ }$ & \\
\hline 18. & $\mathbf{R}$ & 90 & $\sqrt{ }$ & \\
\hline 19. & $\mathbf{S}$ & 70 & $\sqrt{ }$ & \\
\hline 20. & $\mathbf{T}$ & 90 & $\sqrt{ }$ & \\
\hline 21. & $\mathbf{U}$ & 80 & $\sqrt{ }$ & \\
\hline \multicolumn{2}{|c|}{ Jumlah } & 1660 & & \\
\hline \multicolumn{2}{|c|}{ Rata-rata } & 79 & & \\
\hline \multicolumn{2}{|c|}{ Daya serap } & $79 \%$ & & \\
\hline \multirow{2}{*}{\multicolumn{2}{|c|}{$\begin{array}{l}\text { Ketuntasan } \\
\text { belajar }\end{array}$}} & 90,48 & & \\
\hline & & $\%$ & & \\
\hline
\end{tabular}

Untuk memperoleh data di atas penulis menggunakan rumus nilai rata-rata persiklus yaitu :

$$
N R=\frac{\sum X}{N}
$$

Dimana :

$$
\begin{aligned}
& \mathrm{NR}=\text { Nilai rata-rata } \\
& \sum \mathrm{X}=\text { Jumlah Nilai } \\
& \mathrm{N}=\text { Jumlah Siswa } \\
& \mathrm{NR}=1660: 21 \\
& \mathrm{NR}=79
\end{aligned}
$$


Data hasil belajar dalam pembelajaran sumber daya alam dengan pendekatan konstektual siklus pertama dapat dilihat pada tabel bahwa hasil belajar yang dicapai siswa pada siklus pertama ini rata-rata $79 \%$ pada pembelajaran sumber daya alam siklus pertama siswa dinyatakan tuntus hanya 90,48 $\% \quad$ sebagaimana ketentuan Depdiknas (2006) pembelajaran di kelas dikatakan tuntas apabila nilai rata-rata siswa mencapai 65 . Ketuntasan belajar siswa untuk itu perlu kita lanjutkan lagi ke siklus II.

\section{Siklus II}

Seperti halnya pada siklus I pada pertemuan siklus II ini guru memberikan apersepsi yang berhubungan dengan materi pelajaran. Selanjutnya pada akhir pembelajaran dilakukan evaluasi untuk mengetahui keberhasilan pada siklus II ini. Data hasil tes/evaluasi siswa dengan KKM 65 dapat dilihat pada tabel 2 berikut ini:

TabeL 2. Hasil Tes Siklus II

\begin{tabular}{|c|c|c|c|c|}
\hline $\mathbf{N e}$ & $\begin{array}{l}\text { Nama } \\
\text { Siswa }\end{array}$ & $\begin{array}{l}\text { Nilai } \\
\text { Siklus } \\
\text { II }\end{array}$ & $\begin{array}{l}\text { Tunt } \\
\text { as }\end{array}$ & $\begin{array}{l}\text { Belum } \\
\text { Tuntas }\end{array}$ \\
\hline 1. & A & 90 & $\sqrt{ }$ & \\
\hline 2. & B & 100 & $\sqrt{ }$ & \\
\hline 3. & C & 90 & $\sqrt{ }$ & \\
\hline 4. & D & 100 & $\sqrt{ }$ & \\
\hline 5. & $\mathbf{E}$ & 100 & $\sqrt{ }$ & \\
\hline 6. & F & 90 & $\sqrt{ }$ & \\
\hline 7. & G & 80 & $\sqrt{ }$ & \\
\hline 8. & $\mathbf{H}$ & 90 & $\sqrt{ }$ & \\
\hline 9. & I & 90 & $\sqrt{ }$ & \\
\hline 10. & J & 90 & $\sqrt{ }$ & \\
\hline 11. & $\mathbf{K}$ & 100 & $\sqrt{ }$ & \\
\hline 12. & $\mathbf{L}$ & 90 & $\sqrt{ }$ & \\
\hline 13. & $\mathbf{M}$ & 100 & $\sqrt{ }$ & \\
\hline 14. & $\mathbf{N}$ & 90 & $\sqrt{ }$ & \\
\hline 15. & $\mathbf{O}$ & 90 & $\sqrt{ }$ & \\
\hline 16. & $\mathbf{P}$ & 100 & $\sqrt{ }$ & \\
\hline 17. & $\mathbf{Q}$ & 80 & $\sqrt{ }$ & \\
\hline 18. & $\mathbf{R}$ & 80 & $\sqrt{ }$ & \\
\hline 19. & $\mathbf{S}$ & 100 & $\sqrt{ }$ & \\
\hline 20. & $T$ & 90 & $\sqrt{ }$ & \\
\hline & $\mathbf{U}$ & 100 & $\sqrt{ }$ & \\
\hline \multicolumn{2}{|c|}{ Jumlah } & 1940 & & \\
\hline \multicolumn{2}{|c|}{ Rata-rata } & 92,4 & & \\
\hline \multicolumn{2}{|c|}{ Daya serap } & $92,4 \%$ & & \\
\hline \multicolumn{2}{|c|}{$\begin{array}{l}\text { Ketuntasan } \\
\text { belajar }\end{array}$} & $100 \%$ & & \\
\hline
\end{tabular}

Untuk memperoleh data di atas penulis menggunakan rumus nilai rata-rata persiklus yaitu :

$$
N R=\frac{\sum X}{N}
$$

$$
\begin{array}{ll}
\text { Dimana: } & \\
\mathrm{NR} & =\text { Nilai rata-rata } \\
\mathrm{NX} & =\text { Jumlah Nilai } \\
\mathrm{N} & =\text { Jumlah Siswa } \\
\mathrm{NR} & =1940 / 21 \\
\mathrm{NR} & =92,4
\end{array}
$$

Dilihat dari tabel di atas menunjukkan bahwa pada siklus II ini mengalami peningkatan dari siklus I dimana nilai rata-rata yang diperoleh siswa 92,4. Dengan nilai nilai tertinggi 100 dan nilai terendah 80 . Ketuntasan belajar siswa pada siklus II telah mencapai $100 \%$ dan telah mencapai ketuntasan belajar klasikal sebagaimana ketentuan Depdiknas (2006) pembelajaran di kelas dikatakan tuntas apabila nilai rata-rata siswa mencapai $75 \%$ ketuntasan belajar.

\section{PEMBAHASAN}

\section{Siklus I}

Penggunaan media torso di kelas IV SD Negeri 01 Kota Mukomuko Kecamatan Kota Mukomuko pada siklus I terlihat bahwa hasil belajar siswa masih 2 belum tuntas, hal ini dapat dilihat dari rata-rata dan persentase ketuntasan belajar siswa secara klasikal hanya mencapai 79 dengan nilai rata-rata $90,48 \%$. Nilai tertinggi yang diperoleh siswa 100 dan nilai terendah 60. Hasil belajar ini belum dikategorikan tuntas karena ketentuan Depdiknas (2006) bahwa ketuntasan belajar klasikal telah tercapai apabila dalam kelas tersebut sudah mencapai $85 \%$ dari jumlah siswa yang mendapatkan nilai 70 keatas.

Oleh karena itu perlu dilakukan perbaikanperbaikan yang dapat meningkatkan hasil belajar siswa, yakni pada siklus II.

\section{Siklus II}

Dalam kegiatan pembelajaran IPA dengan menggunakan media torso di kelas IV SD Negeri 01 Kota Mukomuko Kabupaten Kota Mukomuko dari siklus I siklus II terlihat bahwa aktivitas guru dan aktivitas siswa selalu mengalami peningkatan, hal ini dapat dilihat dari rata-rata nilai dan persentase ketuntasan belajar siswa secara klasikal pada siklus II mencapai $100 \%$, dengan nilai ratarata 92,4. Nilai tertinggi yang diperoleh siswa 100 dan nilai terendah 80. Hasil belajar ini sudah dikategorikan tuntas karena ketentuan Depdiknas (2006) bahwa ketuntasan belajar klasikal telah tercapai apabila dalam kelas tersebut sudah 
mencapai $85 \%$ dari jumlah siswa yang mendapatkan nilai 70 keatas.

Table 3. Nilai Ketuntasan belajar siswa per-siklus

\begin{tabular}{llcccc}
\hline No & $\begin{array}{l}\text { Nama } \\
\text { Siswa }\end{array}$ & $\begin{array}{l}\text { Nilai } \\
\text { Siklus } \\
\text { I }\end{array}$ & $\begin{array}{l}\text { Ket. } \\
\text { T/T } \\
\text { T }\end{array}$ & $\begin{array}{l}\text { Nilai } \\
\text { Siklus } \\
\text { II }\end{array}$ & $\begin{array}{l}\text { Ket. } \\
\text { T/TT }\end{array}$ \\
\hline 1. & $\mathrm{A}$ & 80 & $\mathrm{~T}$ & 90 & $\mathrm{~T}$ \\
\hline 2. & $\mathrm{B}$ & 80 & $\mathrm{~T}$ & 100 & $\mathrm{~T}$ \\
\hline 3. & $\mathrm{C}$ & 80 & $\mathrm{~T}$ & 90 & $\mathrm{~T}$ \\
\hline 4. & $\mathrm{D}$ & 80 & $\mathrm{~T}$ & 100 & $\mathrm{~T}$ \\
\hline 5. & $\mathrm{E}$ & 80 & $\mathrm{~T}$ & 100 & $\mathrm{~T}$ \\
\hline 6. & $\mathrm{F}$ & 80 & $\mathrm{~T}$ & 90 & $\mathrm{~T}$ \\
\hline 7. & $\mathrm{G}$ & 80 & $\mathrm{~T}$ & 80 & $\mathrm{~T}$ \\
\hline 8. & $\mathrm{H}$ & 60 & $\mathrm{TT}$ & 90 & $\mathrm{~T}$ \\
\hline 9. & $\mathrm{I}$ & 90 & $\mathrm{~T}$ & 90 & $\mathrm{~T}$ \\
\hline 10. & $\mathrm{J}$ & 70 & $\mathrm{~T}$ & 90 & $\mathrm{~T}$ \\
\hline 11. & $\mathrm{K}$ & 100 & $\mathrm{~T}$ & 100 & $\mathrm{~T}$ \\
\hline 12. & $\mathrm{L}$ & 70 & $\mathrm{~T}$ & 90 & $\mathrm{~T}$ \\
\hline 13. & $\mathrm{M}$ & 90 & $\mathrm{~T}$ & 100 & $\mathrm{~T}$ \\
\hline 14. & $\mathrm{N}$ & 80 & $\mathrm{~T}$ & 90 & $\mathrm{~T}$ \\
\hline 15. & $\mathrm{O}$ & 60 & $\mathrm{TT}$ & 90 & $\mathrm{~T}$ \\
\hline 16. & $\mathrm{P}$ & 80 & $\mathrm{~T}$ & 100 & $\mathrm{~T}$ \\
\hline 17. & $\mathrm{Q}$ & 70 & $\mathrm{~T}$ & 80 & $\mathrm{~T}$ \\
\hline 18. & $\mathrm{R}$ & 90 & $\mathrm{~T}$ & 80 & $\mathrm{~T}$ \\
\hline 19. & $\mathrm{S}$ & 70 & $\mathrm{~T}$ & 100 & $\mathrm{~T}$ \\
\hline 20. & $\mathrm{T}$ & 90 & $\mathrm{~T}$ & 90 & $\mathrm{~T}$ \\
\hline 21. & $\mathrm{U}$ & 80 & $\mathrm{~T}$ & 100 & $\mathrm{~T}$ \\
\hline Jumlah & $\mathbf{1 6 6 0}$ & & $\mathbf{1 9 4 0}$ & \\
\hline Rata-rata & $\mathbf{7 9}$ & & $\mathbf{9 2 , 4}$ & \\
\hline Daya & serap & $\mathbf{7 9 \%}$ & & $\mathbf{9 2 , 4 \%}$ & \\
\hline Ketuntasan & $\mathbf{9 0 , 4 8}$ & & $\mathbf{1 0 0 \%}$ & \\
belajar & $\mathbf{0}$ & & & \\
\hline & & & & & \\
\hline
\end{tabular}

Dari tabel di atas digambarkan dengan grafik untuk melihat rata-rata dan ketuntasan belajar antara siklus 1 dan siklus 2. Grafik tersebut dapat dilihat pada Gambar 1.

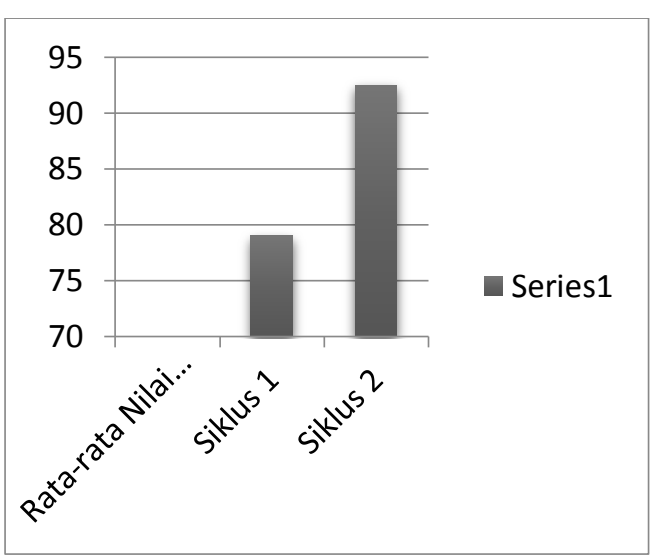

Gambar 1. Rata-rata Nilai Siklus 1 dan 2
Dari grafik di atas tergambar bahwa rata-rata nilai siswa pada siklus 1 sebesar 79 dan siklus ke-2 adalah sebesar 92,4 .

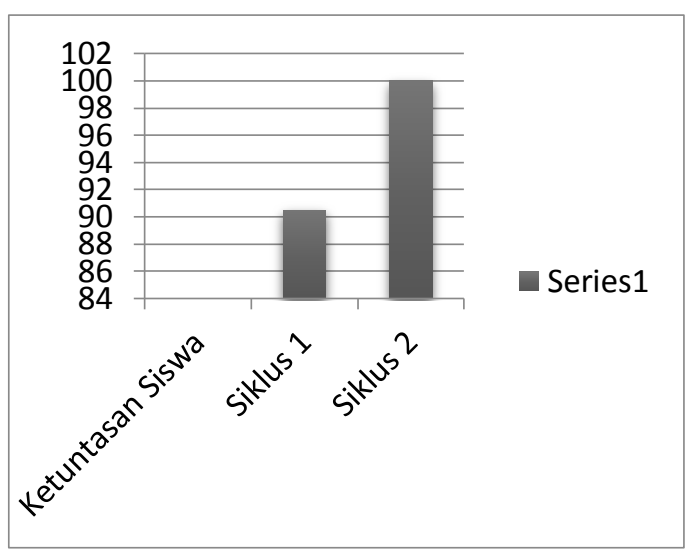

Gambar 2. Grafik Ketuntasan Belajar Siswa

Ketuntasan belajar siswa pada siklus I sebesar 90,48 dan siklus II mencapai 100\%. Jadi dapat disimpulkan bahwa dengan menggunakan media torso dapat meningkatkan hasil belajar siswa pada SD Negeri 01 Kota Mukomuko Pelajaran 2017/2018 dari siklus 1 sampai siklus II mengalami peningkatan belajar.

\section{SIMPULAN DAN SARAN}

Penggunaan media torso dapat meningkatkan hasil belajar siswa pada mata pelajaran IPA di kelas IV SD Negeri 01 Kota Mukomuko. Siswa terlihat lebih aktif dalam proses pembelajaran dibandingkan saat pembelajaran yang dilakukan dengan metode ceramah saja.

Sebagai saran :

1. Bagi Guru Sekolah Dasar

Guru sebaiknya menggunakan media dalam pembelajaran, karena hal itu, mempengaruhi keberhasilan siswa dalam belajar.

2. Bagi Kepala Sekolah

Penggunaan media torso dapat digunakan sebagai salah satu alternatif untuk meningkatkan hasil belajar siswa dalam proses pembelajaran sehingga dorongan kepala sekolah sangat diharapkan supaya dapat memberi motivasi kepada guru agar mempunyai kreativitas dalam pembelajaran.

Bagi siswa

3. Siswa harus membangunkan pengetahuannya tentang rangka manusia

4. Bagi peneliti lain

Peneliti lain disarankan agar memperbaiki kekurangan yang ada dalam penelitian tindakan kelas ini sehingga penggunaan media 
torso dalam pembelajaran IPA benar-benar dilaksanakan.
Susanto.2007. Pengembangan KTSP dengan perspektif manajemen Visi. Jakarta: Mata.

Sukmadinata, Syaodih, N. 2010. Metode Penelitian Pendidikan: Rosda, Bandung.

Susilana, Rudi, 2019. Media Pembelajaran. CV. Wacana Prima. Bandung.

Morgan dkk dalam Departemen Pendidikan dan Kebudayaan (1998/1999: 7)

Dimyati dkk (2009) belajar adalah "suatu perilaku"

2010. Torso. www.wikipedia.org.com, diakses tanggal 5 Januari 2012.

Duffy, Gace L., Scott A. Laman, Pradip Mehta, Rochiati Wiriatmaja. 2005. Metode penelitian Tindakan Kelas.Bandung.PT.Remajaa Rosdakarya.

Sumiati dan asra .2007 Metode pembelajaran: CV Wacana Prima
2010. Produsen Alat Peraga Terlengkap di Indonesia. www.wikipedia.org.com, diakses tanggal 5 Januari 2012. 
